\title{
Müzelerdeki Hizmet Kalitesinin Memnuniyet Algısı ve Tavsiye Etme Niyeti Üzerindeki Etkisi: Anadolu Medeniyetleri Müzesi Örneği
}

\author{
The Impact Of Service Quality On Perception of Satisfaction and Intention To \\ Recommend: The Museum of Anatolian Civilizations Case
}

\author{
Dr. Öğr. Üyesi Ayşe Nevin SERT ${ }^{1}$, Arş. Gör. Dr. S1la KARACAOĞLU²
}

\begin{abstract}
Özet
Yüksek hizmet kalitesinin ve algılanan ziyaretçi memnuniyet seviyesinin müşteri sadakatini ve tavsiye etme niyetini etkilediği söylenebilir. Müzelerde hizmet kalitesinin ölçülmesi bir hizmet boyutunun hangi yönlerinin sorun oluşturabileceğini ortaya koymakta ve böylece problemin giderilmesi için öneriler geliştirilmesine imkan tanımaktadır. Bu çalışmanın amacı Anadolu Medeniyetleri Müzesi'ne yönelik algılanan hizmet kalitesinin memnuniyet algısı ve tavsiye etme niyeti üzerindeki etkisini ölçmektir. Anadolu Medeniyetleri Müzesinde 449 ziyaretçiyle yapılan araştırmada hizmet kalitesi "fiziksel özellikler", "heveslilik", "iletişim", "tüketilenler" ve "empati” olmak üzere 5 boyuttan oluşmuştur. "Fiziksel özellikler" boyutunun memnuniyet ve tavsiye etme niyeti üzerinde en etkili boyut olduğu saptanmıştır. Ayrıca, çalışma sonuçları, algılanan hizmet kalitesinin memnuniyet algısı ve tavsiye etme niyeti üzerinde anlamlı ve pozitif bir etkisi olduğunu göstermiştir.
\end{abstract}

Anahtar kelimeler: Hizmet kalitesi, memnuniyet algısı, tavsiye etme niyeti, Anadolu Medeniyetleri müzesi, Ankara.

\begin{abstract}
It could be claim that high service quality and perceived visitor satisfaction level influence customer loyalty and intention to recommend. Measuring the quality of service in the museums reveals which aspects of a service dimension can pose a problem and thus allows suggestions to be developed to address the problem The purpose of this study is to measure the perceived quality of service for the Museum of Anatolian Civilizations and the effect of the service quality on perception of satisfaction and intention to recommend. In a survey of 449 visitors in the Anatolian Civilizations Museum in Ankara, the service quality dimensions were identified as "tangibility", "responsiveness", "communication", "consumable" and "empathy". Furthermore it has been determined that the "tangibility" dimension is the most effective dimension on satisfaction and intention to recommend. As a further conclusion, the results of the study showed that the perceived service quality has a significant and positive effect on the perceived satisfaction and intention to recommend.
\end{abstract}

${ }^{1}$ Selçuk Üniversitesi, Beyşehir Ali Akkanat Turizm Fakültesi, nevinsert@selcuk.edu.tr, Orcid ID: orcid.org/0000-0003-07519377

2 Çukurova Üniversitesi, Karataş Turizm İşl.ve Otl. Y.O., skaracaoglu @cu.edu.tr, Orcid ID: orcid.org/0000-0001-7724-2188

103 
Key words: Service quality, perception of satisfaction, intention to recommend, the museum of Anatolian Civilizations, Ankara.

Giriş

Hizmet kalitesi, günümüzün rekabetçi ortamında bir kurumun başarısı için önemli belirleyici olarak kabul edilmektedir (Frost ve Kumar, 2000). Algilan yüksek hizmet kalitesi müşteri memnuniyetini oluşturmakta olup memnun olmuş müşteri ise tavsiye etme eğiliminde olmaktadır (Grönroos, 1984). Dolayısıyla modern dünyada diğer hizmet sağlayıcıları gibi müzeler de daha çok ziyaretçi çekebilmek için hizmet kalitesini yükseltmeye çalışmaktadır.

Toplum yaşamında her geçen gün önemi artan müzenin sözlük anlamı, geçmiş dönemlerin sanatsal, kültürel, tarihsel ya da bilimsel ürünlerini derleyen, koruyan ve bu eserlerden koleksiyonlar meydana getirerek depolayan ve sergileyen, halka açı resmi veya özel sanat ve bilim kuruluşlarına verilen isim olarak tanımlanmıştır (Saltuk, 1993). Müzenin yaşayan bir olgu olduğunu dolayısıyla da tanımının toplumdaki gelişmelere paralel olarak değiştiğini belirten Uluslararası Müzecilik Konseyi'ne (International Council of Museums ICOM) göre ise müze, insanoğlunun ve çevresinin somut ile somut olmayan kültürel mirasını, eğitim, çalışma ve insanlığın estetik hazzı için toplayan, koruyan, araştıran, ileten, sergileyen, aynı zamanda halka açık, toplumun ve toplum gelişiminin hizmetinde olan kâr amacı gütmeyen kalıcı bir kuruluştur (ICOM, 2007).

Yukarıdaki tanımlardan da anlaşılacağı gibi müzelerin geleneksel birincil fonksiyonu, nesneleri toplamak, korumak ve incelemek olmaktır (Gilmore ve Rentschler, 2002). Ancak günümüzde müzelerin sadece mevcut ve gelecek nesiller için insanlık mirasını korumakla kalmadığı; aynı zamanda yaşam kalitesine önemli katkılarda bulunduğu, eğitimi desteklediği, turistleri cezbettiği ve bir destinasyonun pazarlanması ile yeni yatırımların yapılmasına katkı sağladığ 1 görülmektedir (Mylonakis ve Kendristakis, 2006). Rekreasyon faaliyetleri değiştikçe, turizm sektöründe önemli bir pazarlama unsuru haline gelen müzelerin de daha fazla turist çektiği söylenebilir. Bu gelişmelere paralel olarak bir yandan temel bir çekicilik unsuru olarak diğer yandan yukarıdaki tanımlarda yer alan toplumsal görevlerini yerine getirmeye çalışan müzelerin hizmetlerini iyileştirme ve geliştirme konusunda göstermiş oldukları çabalar gün geçtikçe artmaktadır (Maher, Clark ve Motley, 2011). Andreasen ve Kotler (2002) müzelerin, diğer eğlence ve boş zaman etkinlikleriyle rekabet etmek zorunda olduklarını belirterek, müzelerin aile gezileri için akvaryumlarla, sanatı anlamak ve zevk almak için kitaplar ile eğitici televizyon programlarıyla, sosyalleşmek için ise filmler ve restoranlarla rekabet etmesi gerektiğini ileri sürmüşlerdir. $\mathrm{Bu}$ nedenle, rekabetçi ortamda hayatta kalmak için müzelerin ve kültürel organizasyonların hizmet kalitesine önem vermeleri ve doğru pazarlama stratejileri geliştirmeleri gerektiğini vurgulamışlardır. Ayrıca Maher vd., (2011) de kaliteli bir hizmetin rekabet avantajı sağladığına ve performans ölçmede iyi bir gösterge olduğuna işaret etmişlerdir.

Müze hizmet kalitesinin ölçümü, kalite yönetimini iyileştirmek amacıyla olumlu ve olumsuz niteliklerin belirlenmesine yardımcı olmaktadır. Çeşitli boyutların genel hizmet kalitesini nasıl etkilediğinin anlaşılması, müzelerin hizmet sunum unsurlarının ve süreçlerinin verimli bir şekilde tasarlanmasını, kaynaklarının en iyi şekilde kullanılmasını sağlamaktadır (Hsieh, Park ve Hitchcock, 2015). Bununla birlikte, ziyaretçilerin 
gereksinimlerine uygun olarak sunulan kaliteli hizmetler müzelerin hem turizm hem de toplumsal açıdan beklenen işlevlerini yerine getirmesini olanaklı kılmaktadır (Markovic, Raspor ve Komsic, 2013). Dolayısıyla, müze yöneticileri kalite stratejilerini yönlendirmek ve hangi unsurların iyileştirilmesi gerektiğini anlamak için hizmet kalitesi boyutlarını tanımlamalarını sağlayacak güvenilir araçlara ihtiyaç duymaktadırlar (Frochot ve Hughes 2000). Bu nedenle, müze ziyaretçilerinin algıladığ1 hizmet kalitesini ölçmek için çeşitli modeller geliştirilmiş ve uygulanmıştır. Söz konusu modellerden bazılar Frochot ve Hughes'ın (2000) geliştirmiş olduğu HISTOQUAL ile Hsieh'in (2010) geliştirmiş olduğu MUSEQUEL dir. Bununla birlikte, müzelerde hizmet kalitesinin diğer hizmet alanlarına göre daha az araştırıldığı söylenebilir.

Buradan hareketle araştırmanın amacı, Anadolu Medeniyetleri Müzesi'ne yönelik algılanan hizmet kalitesini ölçmek bunun yanı sıra hizmet kalitesinin ve faktörlerinin memnuniyet algısı ile tavsiye etme niyeti üzerindeki etkisini ortaya koymaktır.

\section{Hizmet Kalitesi}

Kalite, hizmet ve hizmet kalitesi kavramları çok boyutlu olup yazarlar tarafindan farklı şeklilerde tanımlanmış olup üzerinde anlaşmaya varılmış kesin bir tanımın olmadığı görülmektedir. Uluslararas1 Standartlar Örgütü (International Organization for Standardization- ISO) kalitenin; bir mal veya hizmetin var olan veya olabilecek ihtiyaçları karşılama kabiliyetine dayanan özelliklerinin toplamı olduğunu belirtmiştir (ISO 9000, 2000). Kalite konusunda çalışmalar yürütmüş olan araştırmacılardan Juran (1988), konuya müşteri odaklı yaklaşarak kaliteyi, müşteri beklentilerini karşılayabilme yeteneği ya da kullanıma uygunluk olarak tanımlamıştır. Feigenbaum (1991) kalite kavramının bir mal ya da hizmetin, müşterilerin beklenti ve ihtiyaçlarını en ekonomik düzeyde karşılayabilmesi olduğunu ileri sürmüştür. Efil (1999) ise kaliteyi müşteri tatmini ve memnuniyeti olarak tanımlamıştır. Swarbrooke (2002) da kaliteyi kısaca müşterinin en az maliyetle en çok faydayı elde etmesi olarak ifade etmiştir. Söz konusu tanımlar müşteri gereksinmelerini referans alan müşteri odaklı tanımlardır. Müşteri odaklı tanımlarda kalitenin, müşterilerin tercih ve gereksinmelerinin en iyi şekilde karşılanması anlamına geldiği söylenebilir (Rowley, 1999). Hizmetin kaliteli olması ise, müşterilerin beklentilerini karşılayabilme ya da beklentilerinin ötesine geçebilmektir. Bu noktada müşteri beklentileri, hizmet sağlayıcıların neyi sağlayabileceği değil, müşterinin neyi sağlanması gerektiğini hissettiği ve düşündüğü her şey anlamına gelen talep ve arzuları ifade etmektedir. Diğer bir ifadeyle, hizmet kalitesi müşterilerin bir hizmetten elde etmeyi bekledikleriyle elde ettikleri arasındaki farktır denebilir. (Grönroos, 1984; Spreng ve Mackoy, 1996; Zeithaml ve Bitner, 2000; Seth, Deshmukh ve Vrat, 2005; Yarımoğlu Kursunluoglu, 2014).

Hizmet kalitesinin tam olarak kavranabilmesi için hizmetin özelliklerinin çok iyi anlaşılması gerekmektedir (Dotchin ve Oakland, 1994; Dabholkar, Shepherd ve Thorpe, 2000). Hizmetin heterojen olmas1, üretimin ve tüketimin eş zamanlı olmas1, soyut olmas1, stoklanamamas1, önceden denenememesi gibi doğasından kaynaklanan özelliklerinden dolayı hizmet kalitesinin, diğer sektörlere göre tanımlanmasının ve ölçülmesinin daha zor ve karmaşık olduğu görülmektedir. Bununla birlikte hizmet kalitesinin değerlendirilmesi yalnızca bir hizmetin sonucuyla ilgili olmayıp; aynı zamanda hizmet sunum sürecini de içermesinden dolayı malları değerlendirmekten daha zordur (Parasuraman, Zeithaml ve Berry, 1985). 
Sert ve Karacaoğlu / Müzelerdeki Hizmet Kalitesinin Memnuniyet Algısı ve Tavsiye Etme Niyeti Üzerindeki Etkisi: Anadolu Medeniyetleri Müzesi Örneği / The Impact Of Service Quality On Perception of Satisfaction and Intention To Recommend: The Museum of Anatolian Civilizations Case

Hizmet kalitesi kavramı 1980'lerden itibaren önemli bir konu haline gelmiş olup hizmet kalitesi şemsiyesi altında bir araya getirilen temel kavramların anlaşılması, hizmet kalitesinin müşteriler tarafindan nasıl algılandığının ve hizmet kalitesini etkileyen faktörlerin neler olduğunun belirlenmesi (Grönroos, 1984; Caro ve Garcia, 2008; Hsieh, 2010; Hsieh vd., 2015) amaciyla birçok hizmet kalitesi modeli geliştirilmiştir. Söz konusu modellerde müşteri bakış açısı önemli bir yer tutmuş olup memnuniyeti belirlemek amaciyla müşteri beklentileri ve deneyimleri arasındaki farka odaklanılmıştır (Philip ve Hazlett, 1997; Rust ve Oliver, 2000). Geliştirilen modellerin önemli bir kısmının Parasuraman vd.,'nin (1985) "Hizmet Kalitesi Modeli" temel alınarak yapılandırıldığı görülmektedir (Philip ve Hazlett, 1997). Parasuraman, Zeithaml ve Berry, (1994) geliştirmiş oldukları modelin ve ölçeğin bir "iskelet" olarak kullanılarak farklı alanlara uygulanabileceğini belirtmişlerdir. Buradan yola çıkarak çeşitli alanlarda yapılan çok sayıda ki çalışmada SERVQUAL modeli adapte edilmiştir (Dabholkar, 1996; Philip ve Hazlett, 1997; Frost ve Kumar, 2000; Santos, 2003; Caro ve Garcia, 2008; Huang, Lee ve Chen. 2017).

Hizmet kalitesinin ölçülmesi amacıyla en yaygın olarak kullanılan ölçek SERVQUAL'dir (Parasuraman vd., 1985, 1988; Seth vd., 2005 ). Bu ölçek bir temel yap1 olarak kullanılarak bankacılıktan, turizm, sağlık ve eğlence sektörüne kadar çeşitli alanlarda kullanılmıştır. Ölçek, hizmet kalitesini beklenen hizmet ile algılanan hizmet arasındaki fark olarak hesaplamaktadır (Frost ve Kumar, 2000). Parasuraman vd., (1985) bankacılık, kredi kartı hizmetleri, uzun mesafeli telefon hizmetleri ve tamir-bakım hizmetleri alanında faaliyet gösteren işletmeler ile odak grup görüşmeleri yürüttükleri araştırmaları sonucunda elde ettikleri veriler 1şı̆̆ında müşterilerin hizmet kalitesini değerlendirmede 10 temel hizmet kalitesi boyutu belirlemişlerdir. Bu boyutları; fiziksel unsurlar, güvenilirlik, heveslilik (isteklilik), yeterlilik, nezaket, inanılırlık, güvenlik, ulaşılabilirlik, iletişim ve müşteriyi anlama olarak isimlendirilmiştir. Bununla birlikte, Parasuraman ve arkadaşları 1988 yılında yapmış oldukları çalışmayla 10 hizmet kalitesi boyutunu fiziksel özellikler, heveslilik (isteklilik), güvenilirlik, güvence ve empati olmak üzere 5 boyuta indirgemişlerdir. Söz konusu 5 boyut 22 ifadeden oluşmakta olup 7'li Likert ölçeği kullanılmıştır. Fiziksel özellikler boyutunda tesisler, araç-gereç, iletişim materyalleri ve çalışanların görünüşü; heveslilik (isteklilik) boyutunda müşterilere yardımcı olma ve hizmeti hızlı bir şekilde verme konusunda istekli olma; güvenirlilik boyutunda söz verilen hizmeti doğru ve güvenilir bir şekilde yerine getirebilme yeteneği; güvence boyutunda iş görenlerin bilgisi ve nezaketi ile müşterilere güven aşılama becerisi ve son olarak empati boyutunda ise işletmelerin müşterilerine ilgi ve özen göstermesine ilişkin ifadeler yer almaktadır.

SERVQUAL ölçeği müzelerde hizmet kalitesini ölçmek amacıyla da kulanılmıştır. Bununla birlikte SERVQUAL ölçeğinden yararlanarak geliştirilmiş olan, HISTOQUAL (Frochot ve Hughes, 2000) ve MUSEQUAL (Allen, 2001; Hsieh, 2010; Hsieh vd., 2015) ölçeklerinn de kullanıldığg görülmektedir. Frochot ve Hughes (2000) SERVQUAL'i temel alarak tarihi alanlarda ve müzelerde hizmet kalitesini ölçmek amacıyla yeni bir ölçek geliştirmiş ve bu ölçeği HISTOQUAL olarak adlandırmışlardır. Ölçek beş boyuttan oluşmakta olup bu boyutlar "fiziksel özellikler", "heveslilik", "iletişim", "tüketilenler" ve "empati” dir (Frochot ve Hughes, 2000). Fiziksel özellikler boyutu söz konusu yerin (tarihi ve kültürel alan, müze vb.) çevresinin ve ortamının fiziksel özelliklerini ve durumunu, heveslilik boyutu ise çoğunlukla çalışan verimliliğini ve o yerin ziyaretçilerin ihtiyaçlarını karşılayabilme yeteneğini ifade etmektedir. İletişim boyutu sunulan bilgilerin kalitesini ve detayını yansıtırken empati boyutu çocukların ve engellilerin ihtiyaçlarının nasıl 
karşılandığıyla, tüketilenler boyutu da ziyaret edilen yerin kafeterya ve hediyelik eşya satış yeriyle ilgilidir.

SERVQUAL ve HISTOQUAL'u temel alan müzelerde hizmet kalitesini ölçmede kullanılan diğer bir ölçek de Allen'ın (2001) MUSEQUAL olarak adlandırdığı ölçeğidir. Frochot'ta (2001) olduğu gibi, Allen'da (2001) ziyaret kavramına çeşitli etkenlerin oluşturduğu bütünsel bir deneyim olarak yaklaşmıştır. Allen, MUSEQUAL ölçeğini ortaya koyarken özellikle müze ve galerilere uygulanabilir olmasına çalışmıştır (Black, 2005). Ölçek "fiziksel özellikler", "heveslilik", "iletişim", "tüketilenler" ve "farkındalık" olmak üzere beş boyut ve 24 ifadeden oluşmaktadır.

Müzelerde hizmet kalitesini ölçmeye yönelik geliştirilen bir başka ölçek ise SERVQUAL, HISTOQUAL ve Allen'ın (2001) oluşturduğu MUSEQUAL ölçeklerinden yararlanarak Hsieh (2010) ve Hsieh vd., (2015) nin geliştirdikleri ölçektir. Hsieh (2010) ve Hsieh vd., (2015) de ölçeklerini MUSEQUAL olarak adlandırmışlardır. Hsieh (2010) ve Hsieh vd., (2015) ölçeği "fiziksel özellikler", "heveslilik", "iletişim”, “tüketilenler" ve "empati" olmak üzere beş boyuttan oluşmakta olup 28 ifade içermektedir. Ölçekteki boyutlara ilişkin detaylı bilgilere aşağıda yer verilmektedir.

Fiziksel Özellikler: Müzenin fiziksel özellikleri ve müzede yer alan sergilerin çeşitliliği ve bu sergilerin iyi korunup korunmamasıyla ilgili ifadeleri içermektedir. Çalışanların görünümü bu boyut altında yer almaktadır. Ayrıca diğer ölçeklerde olmayan müzede sergilenen eserlerin çeşitliliği de bu boyutta sorgulanmaktadır. 6 ifadeden oluşmaktadır.

Heveslilik: Çalışanların verimliliğiyle ilgili olan heveslilik boyutu 5 ifadeden oluşmaktadır. Çalışanların ziyaretçilerle ilgilenme biçimlerine, bilgi düzeylerine ve sayılarının yeterliliğine vurgu yapılmaktadır. 5 ifadeden oluşmaktadır.

İletişim: Müzede sergilenen eserlerle ilgili bilgilerin kalitesini, eserlerin sergilenme biçimini ve müzede gezme kolaylığını ifade etmektedir. Bu boyut altında HISTOQUAL ve Allen'ın (2001) MUSEQUAL ölçeğinde 4 ifade varken bu ölçekte 6 ifade yer almakta olup daha detaylidir.

Tüketilenler: Bu boyut müzenin kafeteryası ve hediyelik eşya satış yeriyle ilgilidir. 5 ifade yer almakta olup diğer iki ölçekten de ifade sayısı fazladır. Müzede bulunan kafeterya ve dükkanların hem ürün çeşitliliğini hem de ürün kalitesini ayrı ayrı sorgulamaktadır.

Empati: Çocukların ve engelli ziyaretçilerin ihtiyaçlarının karşılanması, ses ve kalabalığın kabul edilebilir düzeyde olup olmadığı araştırılmaktadır. Bu boyutta yer alan ifadeler HISTOQUAL ve Allen'ın (2001) geliştirmiş olduğu MUSEQUAL ölçeği ile oldukça benzerdir. 6 ifadeden oluşmaktadır.

Bahsi geçen ölçekler çeşitli çalışmalarda kullanılmıştır. Williams (1998) yaptığı çalışmada SERVQUAL ölçeğinin İngiltere'deki boş zaman endüstrisinin hizmet kalitesini ölçmeye uygun olup olmadığını araştırmıştır. Çalışmanın alan araştırması sanat galerisi, tiyatro, eğlence parkı, golf sahası, dinlence merkezi ve müze olmak üzere altı farklı rekreasyon alanında yürütülmüştür. Williams (1998) ölçeğin kar amacı gütmeyen hizmet 
Sert ve Karacaoğlu / Müzelerdeki Hizmet Kalitesinin Memnuniyet Algısı ve Tavsiye Etme Niyeti Üzerindeki Etkisi: Anadolu Medeniyetleri Müzesi Örneği / The Impact Of Service Quality On Perception of Satisfaction and Intention To Recommend: The Museum of Anatolian Civilizations Case

sektöründen ziyade kar amacı güden hizmet sektöründe uygulanmasının daha güvenilir olduğunu öne sürmüştür. Goulding'in (2000), Birmingham Müzesi ve Sanat Galerisi'ndeki ziyaretçileri gözlemlemesi sonucunda, hizmet deneyiminin bir dizi sosyo-kültürel (sosyal etkileşim, uyarı çeşitliliği, temanın ve hikayenin sürekliliği), bilişsel (öz değerlendirme, hayal gücü, algılanan özgünlük) ve çevresel (kalabalık, oturma yerleri, gürültü) etkilerle oluştuğu sonucuna varmıştır. Caldwell (2002) tarafından Londra'da on bir müzede görüşme tekniğiyle gerçekleştirilmiş olan çalışma ziyaretçilerin kararlarını etkileyen faktörlerin, geleneksel ziyaretçi memnuniyet anketlerinde ölçülenden çok daha fazla olduğunu göstermiş olup müzelerde sergilenen eserlerin, ziyaretçilerin müze seçimine etki eden en önemli belirleyici olduğu bulgulanmıştır. Gilmore ve Rentschler (2002) İrlanda ve Avustralya'da sekiz müzede yapmış oldukları çalışmada ise müzelerdeki hizmet sunumunda yer alan önemli faktörleri iç ve dış etkenler olmak üzere ikiye ayırmışlardır. Dış etkenleri eğitim, ulaşılabilirlik ve iletişim; iç etkenleri ise müze çalışanları ve yöneticileri arasındaki iletişim ve işbirliği, personelin bilgi ve hizmet sunma becerisi, yöneticiler, personel, gönüllüler ve ziyaretçiler arasındaki geribildirim ile iletişim olarak tespit etmişlerdir. Banka ve müzelerdeki hizmet kalitesini karşılaştıran Maher ve Clark (2005) butik müzeler ve küçük banka şubelerinde yapmış oldukları çalışmada bu iki kuruluşun hizmet kalitesini incelemişlerdir. Yazarlar, müzelerde fiziksel özelliklerin, bankalarda ise güvenilirliğin öne çıktığını bulgulamışlardır. Müzelerdeki hizmet kalitesini ele alan başka bir araştırma da Nowacki'e (2005) aittir. Nowacki (2005) SERVQUAL ölçeğini Polonya Ulusal Müzesi'nin bir uzantısı olan Rogalin Sarayı'nın turistik hizmet kalitesini ölçmek amacıyla kullanmıştır. $\mathrm{Bu}$ çalışmada sergilerin, içeriği, estetiği, düzenlenmesi ve sergilenen yerin ambiyansının ziyaretçi tatminini en çok etkileyen faktörler olduğu tespit edilmiştir. Hui-Ying ve ChaoChien (2008), ise Tayvan'da bulunan Ulusal Tarih Öncesi Müzesi’nde 439 kişiyle yapmış oldukları çalışmayla hizmet kalitesi ve müşteri memnuniyeti arasındaki ilişkiyi açıklamaya çalışmışlardır. SERVQUAL ölçeğini kullanan araştırmacılar hizmet kalitesini; eğitsel (eğitici), eğlence, heveslilik ve güven, fiziksel özellikler, ilgi, güvenilirlik ve uygunluk olmak üzere altı boyutta incelemişlerdir. Çalışmada, en üst düzeyde ziyaretçi memnuniyeti sağlayabilmek için hizmet kalitesinin geliştirilmesi gerektiği belirtilmiştir. Lin (2009) Tayvan'ın başkenti Taipei'de Güzel Sanatlar Müzesi'nde yapmış olduğu çalışmada hizmet kalitesini etkileyen faktörleri; temel ürün, beklenen ürün ve zenginleştirilmiş ürün olmak üzere üç başlık altında inceleyerek farklı bir yaklaşım sergilemiştir. Temel ürün başlığı altında; sergilenen eserlere ait açıklayıcı bilgileri içeren etiketler, yönlendirme işaretleri, sergilenen eserler, müze broşürlerinin kalitesi, sergileme tekniği, interaktif sergileme ve iyi iletişim becerisine sahip müze rehberleri yer almaktadır. Beklenen ürünler; konforlu bir ortam, yardımsever müze personeli, uygun giriş ücreti, atölyeler ve interaktif multimedya olanaklarıdır. Zenginleştirilmiş ürünleri ise; müzeyi bulmayı kolaylaştıran yol ve sokak işaretleri, yeterli sayıda ve temiz tuvaletler, müzenin daha uzun süre açık kalması, yeterli park yeri, çekici ürünlere sahip hediyelik eşya satış yeri ve kaliteli yiyecek-içecek işletmelerinin bulunması oluşturmaktadır.

Mey ve Mohamed (2010) hizmet kalitesi, müşteri memnuniyeti ve davranışsal niyet arasındaki ilişkiyi incelemişlerdir. Araştırma Malezya'daki müzelerde gerçekleştirilmiş olup SERVPERF modeli kullanılmıştır. Hizmet kalitesi altı boyut ve otuz dokuz alt boyut ile ölçülmüştür. Boyutlar müzenin ulaşılabilirliği, bilgi kaynakları, sergi kalitesi, müşteri hizmetleri, imkanlar / kolaylıklar ve fiyat olarak belirlenmiştir. Maher vd., (2011) ise SERVQUAL'in çocuk müzelerindeki boyutlarını ortaya koymayı amaçlamışlardır. Yazarlar yürütmüş oldukları araştırmanın sonunda hizmet kalitesi boyutlarından "empati" nin öne 
çıktığını belirtmişlerdir. Bununla birlikte Cheng ve Wan (2012) ise HISTOQUAL ölçeğini kullanmış ve Çin'deki Macao Müzesi'nde hizmet kalitesini incelemiş olup ziyaretçilerin hizmet kalitesi algılarının müze türlerine göre farklılık gösterdiğini ortaya koymuşlardır. Markovic vd., de (2013) çalışmalarında, müze hizmet kalitesini ölçmek amacıyla HISTOQUAL ölçeğinden yararlanmışlardır. Hırvatistan'da Krapina Neandertal Müzesi’nde yapılan araştırmada ziyaretçi algılarının; fiziksel özellikler, erişilebilirlik, sergi düzeni, empati ve iletişiminden oluşan beş hizmet kalitesi boyutuyla açıklandığını ileri sürmüşlerdir. Wu ve Li (2015) hizmet kalitesinin boyutları ile hizmet kalitesi, memnuniyet, duygu ve davranışsal niyet arasındaki ilişkileri inceledikleri çalışmalarında dört temel hizmet kalitesi boyutu ve bunlara ait on iki alt boyut ortaya koymuşlardır. Bu dört temel boyut etkileşim kalitesi, fiziksel çevre kalitesi, sonuç kalitesi ve erişim kalitesidir. Hsieh vd., (2015) ise Tayvan'da bulunan Ulusal Doğa Bilimleri Müzesinde 405 kişi ile yapmış oldukları çalışmada müzelerde hizmet kalitesini MUSEQUAL ve HISTOQUAL ölçeklerinden yararlanarak incelemişlerdir.

\section{Müşteri Memnuniyeti}

Zeithaml ve Bitner (2000) hizmet kalitesi ile yakın ilişki içinde olan müşteri memnuniyetini bir mal ve/veya hizmetin müşteri ihtiyaç ve beklentilerini karşılayıp karşılamaması açısından değerlendirilmesi olarak tanımlanmaktadır. Diğer bir ifadeyle müşteri memnuniyeti, mal ve/veya hizmetin performansına bağlı bir beklentinin onaylanma ve/veya onaylanmama durumuna ilişkin kişinin tutumu olarak da ifade edilebilir (Taylor ve Cronin, 1994; Duman, 2003). Söz konusu tutum, müşterinin bilişsel ve duygusal süreçleriyle ilgili olup bu süreç müşteri tarafindan memnuniyet ya da memnuniyetsizlik ile sonuçlanmaktadır. Bu bağlamda müşteri memnuniyeti, tüketicilerin mal ve hizmetlere ilişkin vermiş olduğu tepkilerdir de denebilir (Rust ve Oliver, 2000).

Müşteri memnuniyetinin oluşumu ve memnuniyeti etkileyen değişkenler ile ilgili farklı teorik yaklaşımlar bulunmaktadır. Söz konusu yaklaşımlar; beklentilerin onaylanmaması bilişsel ya da bilişsel uyumsuzluk, eşitlik, benzeşim, benzeşim-karşıtlık, kıyaslama düzeyi ve uyumlaştırma düzeyi kuramları olarak sıralanabilir. Bu yaklaşımlardan beklentilerin onaylanmaması kuramında, onaylanmama müşterinin hizmet performansını, beklentiyle karşılaştırması anlamına gelir. Başka bir ifade ile müşteri satın alma faaliyeti öncesinde bazı iç ve dış faktörlerin etkisi ile çeşitli beklentiler geliştirir, satın alma ve/veya tüketim esnasında ve sonrasında algıladığı performans ile satın alım öncesi beklentilerini kıyaslar (Eskiler ve Altunışık, 2015). Oliver'ın Tüketici Memnuniyeti Teorisi ve Modeli'ne göre müşteriler bu kıyaslamayı yaparken memnuniyet ve memnuniyetsizlik duygularına dolaysız neden olan üç temel unsur bulunmaktadır. Bunlar; ürün kullanımı veya tecrübesi sonucu ortaya çıkan sonuçlar ile beklentilerin karşılaştırılması ile oluşan uyum/uyumsuzluk algısı, his yumağ1 ve ürün kullanımı veya ürün tecrübesi sonucu ortaya çıkan diğer sonuçlar (kişiler arasındaki ilişkilere yönelik sonuçlar vb.) ile diğer standartların karşılaştırılması sonucu ortaya çıkan uyum ve/veya uyumsuzluklardır. His yumağının oluşmasında, uyum ve/veya uyumsuzluk algısı, sonuçlara yönelik atıfta bulunma ve diğer uyumsuzluklara dolaysiz sebebiyet vermektedir (Duman, 2003).

Turizm endüstrisi ağırlıklı olarak hizmet üreten bir özelliğe sahip olduğundan turistin deneyimlerinden sonra edindiği duygusal durum müşteri memnuniyetini belirlemektedir (Baker ve Crompton 2000). Bu nedenle, pek çok müze işletmesinin ziyaretçi 
memnuniyetini sağlamaya çalışması şaşırtıcı bir durum değildir (Falk, 2009). Günümüzde müze müdürleri ve işletmecileri, ziyaretçileri başarılarının önemli bir unsuru ve bütünleşik pazarlama stratejilerinin bir parçası olarak görmektedir. $\mathrm{Bu}$ bağlamda ziyaretçi memnuniyetini de müze deneyiminin ve hizmet kalitesinin önemli bir parçası olarak benimsemektedirler (McLean, 1994; Kawashima, 1998; Hui-Ying ve Chao-Chien, 2008; Lin, 2009; Mey ve Mohamed, 2010; Wu ve Li, 2015). Dolayssiyla, özellikle müze pazarlamasıyla ilgili kişiler, müzeyi tekrar ziyaret etme ve ziyaret edenlerin müzeyi başkalarına tavsiye etme davranışını etkileyen memnuniyet olgusuna önem vermektedirler (Harrison ve Shaw, 2004).

\section{Tavsiye Etme Niyeti}

Alanyazında yer alan pek çok araştırma, algılanan hizmet kalitesinin müşterilerin davranışsal niyetlerini ve tavsiye etme davranışlarını etkilediğini ortaya koymaktadır. Çalı̧̧malarda müşterilerin daha önce deneyimledikleri mal ve/veya hizmetlerden tatmin olup olmama durumlarının müşteri sadakatini, marka itibarını ve davranışsal niyetlerini etkilediği görülmektedir. (Oliver, 1980; 1981; Zeithhaml, Berry ve Parasuraman, 1996; Zeithaml ve Bitner, 2000; Huang, vd., 2017). Burton ve Scott (2003) müzeyi oluşturan unsurlara (çalışanlar, olanaklar, sergiler vb.) ilişkin memnuniyetin tekrar ziyaret etme ve müzeyi başkalarına tavsiye etme niyetlerini etkilediğini savunmaktadır. Harrison ve Shaw (2004) Avustralya' da küçük bir metropolitan müzesinde 184 ziyaretçi ile yüz yüze görüşme yöntemi ile topladıkları veri sonucunda müze deneyiminden yüksek düzeyde tatmin olmuş ziyaretçilerin hem müzeyi yeniden ziyaret etme niyetlerinin hem de başkalarına tavsiye etme niyetlerinin yüksek olduğunu bulgulamıştır (Harrison ve Shaw, 2004). Hsieh (2010) çalışmasında, müze deneyiminden genel olarak memnun olan ziyaretçilerin müze sadakatlerinin daha yüksek düzeyde olduğunu ve müzeyi ziyaret eden katılımcıların müze deneyimi algılarının müzeyi tekrar ziyaret etme ile başkalarına tavsiye etme niyetleri üzerinde pozitif bir etkiye sahip olduğunu tespit etmiştir. Huo ve Miller (2007) Samoa Adası'nda bulunan Robert Louis Stevenson Müzesi'ni ziyaret eden 112 katılımcidan elde ettikleri veri sonucunda müze deneyiminden yüksek memnuniyet duyduğunu ifade edenlerin, müzeyi başkalarına tavsiye etme niyetlerinin de yüksek olduğunu bulgulamışlardır.

Sonuç olarak yukarıdaki bilgiler 1şı̆̆ında yüksek hizmet kalitesi algılanan ziyaretçi memnuniyet seviyesini ve tavsiye etme niyetini etkilediği söylenebilir. Müşteri eğer mal ve/veya hizmetin kalitesinden memnunsa fiyat artışlarına karşı daha hoşgörülü olmaktadır ve söz konusu mal ve/veya hizmeti tavsiye ederek ününün artmasına hatırı sayılır şekilde katkı sağlayabilmektedir (Baker ve Crompton, 2000). Reid ve Reid'e (1993) göre hizmet kalitesinden memnun müşteriler arkadaşlarına, yakın çevrelerine ve akrabalarına bilgi sağlayan bir kaynak olmalarından dolayı son derece önem arz etmektedir.

İncelenen alan yazın doğrultusunda Anadolu Medeniyetleri Müzesi ziyaretçilerinin hizmet kalitesi algılarına ilişkin olarak aşağıdaki hipotezler geliştirilmiştir:

H1: Alg1lanan hizmet kalitesinin memnuniyet alg1s1 üzerinde anlamlı ve pozitif bir etkisi vardır.

H2: Alg1lanan hizmet kalitesinin tavsiye etme niyeti üzerinde anlamlı ve pozitif bir etkisi vardır. 


\section{Yöntem}

Betimsel bir nitelik taşıyan bu çalışmanın evreni, Anadolu Medeniyetleri Müzesi'ni 5 Aralık 2017 ile 20 Ocak 2018 tarihleri arasında ziyaret eden bireylerden oluşmaktadır. Çalışmada zaman ve maliyet kısıtlarından dolayı örneklem alınma yoluna gidilmiş olup kolayda örnekleme yöntemi ile ulaşılan 449 kişi örneklem grubunu oluşturmuştur.

Araştırmada veri toplama tekniği olarak 4 bölümden oluşan anket kullanılmıştır. Birinci bölümde müzelerde algılanan hizmet kalitesini ölçmeye yönelik 5 faktör (boyut) ve 25 maddeden oluşan algılanan hizmet kalitesi ölçeği kullanılmıştır. Bu ölçeğin oluşturulmasında, Hsieh'in (2010) ve Hsieh vd., (2015) ölçeklerinden yararlanılmıştır. Hsieh'in (2010) ve Hsieh vd., (2015) ölçeğinde 28 ifade yer almakta olup, bu çalışmada 3 ifade Anadolu Medeniyetleri Müzesinde rehber ve uzman bulunmadığı için çıkarılmıştır.

İkinci bölümde ise ziyaretçilerin genel memnuniyet algısını belirlemeye yönelik 1 madde yer alırken üçüncü bölüm de tavsiye etme niyetlerini belirlemeye yönelik 2 madde yer almaktadır. Genel memnuniyet algısının belirlenmesine yönelik ifade Spreng ve Mackoy’un (1996) araştırmasından adapte edilmiştir.

Tavsiye etme niyetini ölçmeye yönelik 2 madde ise Hosany vd., (2015) çalışmasından alınmıştır. Anketin dördüncü bölümünde ise ziyaretçilerin sosyo-demografik özelliklerine ait 6 soruya (cinsiyet, medeni durum, yaş, eğitim durumu, meslek, aylık gelir) yer verilmiştir. Ölçeklerdeki her bir madde 5'li Likert tipi derecelendirmeye tabi tutulmuştur. Hizmet kalitesi ve tavsiye etme ölçeği 1-kesinlikle katılmıyorum/5-kesinlikle katılıyorum aralığında puanlandırılırken, genel memnuniyet ölçeği 1 -kesinlikle memnun değilim/5kesinlikle memnunum olarak derecelendirilmiştir.

Verilerin SPSS 18.0 for Windows paket programı kullanılarak analiz edildiği çalışmada, ziyaretçilerin sosyo-demografik özellikleri frekans ve yüzde dağılımları ile sunulmuş olup, her bir madde ve faktöre ilişkin aritmetik ortalama ve standart sapma değerleri hesaplanmıştır. Bununla birlikte, Anadolu Medeniyetleri Müzesi'ne ilişkin algılanan hizmet kalitesi ölçeğinin yapı geçerliğine yönelik faktör analizi uygulanmış, güvenirlik analizine yönelik iç tutarlığı için ise Cronbach's Alpha katsayıları hesaplanmıştır. Ayrıca, değişkenler (ölçekler) arasındaki ilişkiler için Spearman korelasyon katsayısı hesaplanırken, algilanan hizmet kalitesinin memnuniyet algis1 ve tavsiye etme niyeti üzerindeki etkisi ise çoklu doğrusal regresyon analizi ile belirlenmiştir.

\section{Bulgular}

Araştırmanın örneklem grubunda yer alan toplam 449 bireyin sosyo-demografik özelliklerine göre dağımı Tablo 1'de sunulmuştur. Buna göre, katılımcıların \%57'si kadın, $\% 70,6$ 's evli, \%48,1'i 40 yaşın altında ve $\% 71,3$ 'de en az üniversite mezunudur. Katılımcıların \%37,6's1 memur, \%35'i serbest meslek sahibi olup, \%55,2'sinin aylık hane gelirinin de 4500 TL'nin üzerinde olduğu gözlenmiştir. 
Tablo 1. Katılımcıların sosyo-demografik özelliklerine göre dağılımı

\begin{tabular}{llrr}
\hline Değissken & Gruplar & Sayı (f) & Yüzde (\%) \\
\hline Cinsiyet & Kadın & 256 & 57,0 \\
& Erkek & 193 & 43,0 \\
\hline Medeni durum & Evli & 317 & 70,6 \\
& Bekar & 132 & 29,4 \\
\hline Yaş & 29 ve altı & 75 & 16,7 \\
& $30-39$ & 141 & 31,4 \\
& $40-49$ & 152 & 33,9 \\
Eğitim durumu & 50 ve üzeri & 81 & 18,0 \\
& Ortaokul ve altı & 6 & 1,3 \\
& Lise & 123 & 27,4 \\
& Üniversite & 238 & 53,0 \\
Leslek & Lisansüstü & 82 & 18,3 \\
\hline Isçi & 22 & 4,9 \\
& Memur & 169 & 37,6 \\
& Serbest meslek & 157 & 35,0 \\
& Öğrenci & 40 & 8,9 \\
& Ev hanımı & 35 & 7,8 \\
& Emekli & 26 & 5,8 \\
\hline Aylık gelir & 2500 TL ve altı & 9 & 2,0 \\
& 2501-4500 & 192 & 42,8 \\
& 4501-6500 & 57 & 12,7 \\
& 6501-8500 & 119 & 26,5 \\
& 8501 ve üzeri & 72 & 16,0 \\
\hline Toplam & & $\mathbf{4 4 9}$ & $\mathbf{1 0 0 , 0}$ \\
\hline
\end{tabular}

Anadolu Medeniyetleri Müzesi'ne ilişkin algılanan hizmet kalitesi ölçeğinin yap1 geçerliğine yönelik faktör analizi sonuçları, madde ve faktör ortalama standart sapma değerleri ile iç tutarlığına ait Cronbach's Alpha katsayıları Tablo 2'de sunulmuştur. Buna göre, $\operatorname{KMO}(0,831)$ ve Bartlett's test sonuçları $\left(\chi^{2}=2237,517 ; \mathrm{p}<0,001\right)$ örneklem yeterliği çerçevesinde faktör analizinin uygulanabilirliğini ortaya koymaktadır.

Tablo 2'deki bulgulara göre, toplam 25 maddeden oluşan ölçek, özdeğeri (eigenvalue) 1'den büyük ve toplam varyansın \%69,454'ünü açılayan 5 faktör altında toplanmaktadır. Birinci faktör olan "fiziksel özellikler" toplam varyansin \%24,456'sını açılarken, bunu sırasıyla \%17,527'lik oran ile "tüketilenler", \%9,992'lik oran ile "empati", $\% 9,786$ 'lık oran ile "iletişim" ve \%7,692'lik oran ile "heveslilik" faktörleri izlemektedir. Ölçeğin geneli için Cronbach's Alpha katsayısı 0,831 olarak hesaplanmış olup, her bir faktör için de 0,70 değerinin üzerindedir. Diğer taraftan, madde ve faktörlere ilişkin aritmetik ortalama değerleri incelendiğinde, katılımcıların genel algılanan hizmet kalitesi skorlarının 5'li Likert ölçeğinde orta değer olan 3'ün üzerinde olumlu $\overline{\mathrm{X}} \pm \mathrm{SS}=3,71 \pm 0,23$ olduğu

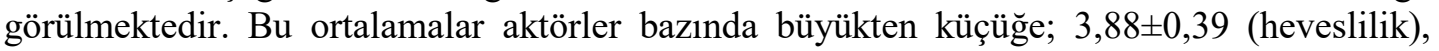

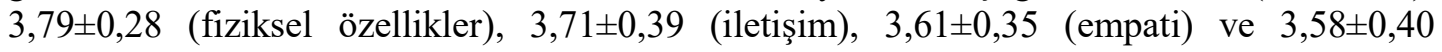
(tüketilenler) şeklinde sıralanmıştır. Madde ortalamaları incelendiğinde, genel olarak 3 olan orta değerin üzerinde olumlu bir alg1 olduğu, ancak diğer konulara göre en eleştirel veya olumsuz yaklaşımın "Yeterli park yeri vardır" $(\overline{\mathrm{X}} \pm \mathrm{SS}=1,97 \pm 0,94)$ ve "Engelli ziyaretçilerin müzeyi rahatlıkla gezebilmeleri için gerekli düzenlemeler yapılmıştır" $(\overline{\mathrm{X}} \pm \mathrm{SS}=2,43 \pm 0,98)$ maddelerinde olduğu belirlenmiştir. 
Tablo 2. Algılanan hizmet kalitesi ölçeğine yönelik faktör analizi sonuçları, ortalama \pm s.sapma değerleri ve Cronbach's Alpha katsayıları

\begin{tabular}{|c|c|c|c|c|}
\hline Faktörler/Maddeler & $\begin{array}{c}\text { Faktör } \\
\text { Yükü }\end{array}$ & $\begin{array}{c}\text { Özdeğer } \\
\text { (\% Varyans) }\end{array}$ & $\bar{X} \pm \mathbf{S S}$ & $\begin{array}{c}\text { Cronbach's } \\
\text { Alpha }\end{array}$ \\
\hline Faktör 1: Fiziksel Özellikler & & \multirow{8}{*}{$\begin{array}{c}3,947 \\
(\% 24,456)\end{array}$} & $3,79 \pm 0,28$ & \multirow{8}{*}{0,754} \\
\hline Yeterli park yeri vardır. & 0,723 & & $1,97 \pm 0,94$ & \\
\hline Yeterli sayıda tuvalet vardır. & 0,687 & & $3,81 \pm 0,60$ & \\
\hline Müze görevlileri iyi giyimlidir. & 0,667 & & $3,98 \pm 0,40$ & \\
\hline Sergiler iyi korunmaktadır. & 0,557 & & $3,96 \pm 0,49$ & \\
\hline Müze temizdir. & 0,548 & & $4,48 \pm 0,55$ & \\
\hline Müzede oturma yerleri yeterlidir. & 0,538 & & $4,08 \pm 0,58$ & \\
\hline Müzede sergilenen eserler çok çeşitlidir. & 0,458 & & $4,27 \pm 0,53$ & \\
\hline Faktör 2: Tüketilenler & & \multirow{6}{*}{$\begin{array}{c}2,829 \\
(\% 17,527)\end{array}$} & $3,58 \pm 0,40$ & \multirow{6}{*}{0,846} \\
\hline Kafeterya personeli iyi hizmet vermektedir. & 0,733 & & $3,78 \pm 0,48$ & \\
\hline $\begin{array}{l}\text { Kafeterya kaliteli -yiyecek-içecek } \\
\text { sunmaktadır }\end{array}$ & 0,680 & & $3,66 \pm 0,53$ & \\
\hline Hediyelik eşya satış yerinde çeşidi çoktur. & 0,615 & & $3,41 \pm 0,70$ & \\
\hline Kafeteryada yiyecek içecek çeşidi boldur. & 0,547 & & $3,37 \pm 0,70$ & \\
\hline $\begin{array}{l}\text { Hediyelik eşya satış yeri kaliteli ürünler } \\
\text { satmaktadır. }\end{array}$ & 0,480 & & $3,70 \pm 0,59$ & \\
\hline Faktör 3: Empati & & \multirow{5}{*}{$\begin{array}{c}1,613 \\
(\% 9,992)\end{array}$} & $3,61 \pm 0,35$ & \multirow{6}{*}{0,783} \\
\hline $\begin{array}{l}\text { Müze atmosferi sergilenen eserlere } \\
\text { uymaktadır. }\end{array}$ & 0,712 & & $4,19 \pm 0,47$ & \\
\hline $\begin{array}{l}\text { Müzedeki ziyaretçi yoğunluğu rahatsız } \\
\text { etmemektedir. }\end{array}$ & 0,693 & & $4,04 \pm 0,44$ & \\
\hline Gürülttü kabul edilebilir düzeydedir. & 0,616 & & $4,01 \pm 0,50$ & \\
\hline $\begin{array}{l}\text { Engelli ziyaretçilerin müzeyi rahatlıkla } \\
\text { gezebilmeleri için gerekli düzenlemeler } \\
\text { yapılmıştır. }\end{array}$ & 0,512 & & $2,43 \pm 0,98$ & \\
\hline Çocuklar için imkânlar yeterlidir. & 0,471 & & $3,39 \pm 0,84$ & \\
\hline Faktör 4: İletişim & & \multirow{6}{*}{$\begin{array}{c}1,579 \\
(\% 9,786)\end{array}$} & $3,71 \pm 0,39$ & \multirow{6}{*}{0,732} \\
\hline $\begin{array}{l}\text { Yönlendirme işaretleri müzede gezmeyi } \\
\text { kolaylaştırmaktadır. }\end{array}$ & 0,591 & & $3,55 \pm 0,87$ & \\
\hline $\begin{array}{l}\text { Genel olarak, sergileme iyi yapılmıştır ( } \\
\text { İşaretlerin boyutu, tasarım, 1şığın parlaklığı). }\end{array}$ & 0,568 & & $4,09 \pm 0,48$ & \\
\hline $\begin{array}{l}\text { Yol ve sokak işaretleri müzeyi bulmayı } \\
\text { kolaylaştırmaktadır. }\end{array}$ & 0,554 & & $3,67 \pm 0,74$ & \\
\hline $\begin{array}{l}\text { Broşürler ve web sitesi yeterli bilgi } \\
\text { sunmaktadır. }\end{array}$ & 0,454 & & $3,23 \pm 0,83$ & \\
\hline $\begin{array}{l}\text { Müze eserleri hakkındaki açıklayıcı yazılar } \\
\text { anlaşı1lırdır (metinler ve grafikler). }\end{array}$ & 0,411 & & $4,01 \pm 0,64$ & \\
\hline Faktör 5: Heveslilik & & \multirow{4}{*}{$\begin{array}{c}1,242 \\
(\% 7,692)\end{array}$} & $3,88 \pm 0,39$ & \multirow{4}{*}{0,716} \\
\hline $\begin{array}{l}\text { Müze personeli ziyaretçilerin isteklerine } \\
\text { anında cevap vermektedir. }\end{array}$ & 0,547 & & $3,88 \pm 0,48$ & \\
\hline $\begin{array}{l}\text { Müze personeli ziyaretçilere yardımcı olma } \\
\text { konusunda isteklidir. }\end{array}$ & 0,464 & & $3,89 \pm 0,51$ & \\
\hline Müze personeli cana yakındır. & 0,423 & & $3,86 \pm 0,50$ & \\
\hline GENEL & & $(\% 69,454)$ & $3,71 \pm 0,23$ & 0,831 \\
\hline
\end{tabular}

Extraction Method: Principal Component Analysis. Rotation Method: Varimax with Kaiser Normalization

Kaiser-Meyer-OlkinMeasure of SamplingAdequacy $(K M O)=0,851$ Bartlett's Test of Sphericity: Chi-Square=2237,517; $d f=300 ; p<0,001$ 
Anadolu Medeniyetleri Müzesi'ni ziyaret edenlerin genel memnuniyet algisı ve tavsiye etme niyetlerine ilişkin frekans ve yüzde dağılımları ile ortalama ve standart sapma değerleri Tablo 3 'te verilmiştir. Buna göre katılımcıların genel memnuniyet düzeylerinin ( $\overline{\mathrm{X}} \pm \mathrm{SS}=4,21 \pm 0,43)$ ve tavsiye etme niyetlerinin ( $\overline{\mathrm{X}} \pm \mathrm{SS}=4,31 \pm 0,46 ; 4,39 \pm 0,49)$ oldukça yüksek olduğu görülmektedir.

Katılımcıların yaklaşık tamamı $(\% 98,8)$ "çok" ve "tam” seçenekleriyle genel bir memnuniyet algısı içerisinde olduklarını belirtmişlerdir. Aynı şekilde, katılımcıların hemen hemen tamamı Anadolu Medeniyetleri Müzesi hakkında olumlu şeyler söyleyeceğini ve Anadolu Medeniyetleri Müzesi'ni arkadaşlarına ve yakın çevresine tavsiye edeceğini belirtmiştir.

Tablo 3. Genel memnuniyet algısı ve tavsiye etme niyetlerine ilişkin betimsel istatistikler

\begin{tabular}{|c|c|c|c|c|c|c|c|c|}
\hline \multirow[b]{2}{*}{ Maddeler } & & \multicolumn{5}{|c|}{ Memnuniyet/Katılım Düzeyi } & \multirow[b]{2}{*}{$\bar{X}$} & \multirow[b]{2}{*}{ SS } \\
\hline & & $\begin{array}{c}\text { Hiç } \\
(1)\end{array}$ & $\begin{array}{l}\mathbf{A z} \\
(2)\end{array}$ & $\begin{array}{c}\text { Orta } \\
(3)\end{array}$ & $\begin{array}{l}\text { Çok } \\
(4)\end{array}$ & $\begin{array}{c}\text { Tam } \\
(5)\end{array}$ & & \\
\hline \multicolumn{9}{|l|}{ Genel Memnuniyet Algısı } \\
\hline Müzenin tüm imkan ve & $\mathrm{f}$ & 0 & 0 & 5 & 345 & 99 & \multirow[b]{2}{*}{4,21} & \multirow[b]{2}{*}{0,43} \\
\hline $\begin{array}{l}\text { hizmetleriyle ilgili genel olarak } \\
\text { memnuniyet düzeyim... }\end{array}$ & $\%$ & 0,0 & 0,0 & 1,1 & 76,8 & 22,0 & & \\
\hline \multicolumn{9}{|l|}{ Tavsiye Etme Niyeti } \\
\hline Anadolu Medeniyetleri Müzesi & $\mathrm{f}$ & 0 & 0 & 1 & 308 & 139 & \multirow[b]{2}{*}{4,31} & \multirow[b]{2}{*}{0,46} \\
\hline $\begin{array}{l}\text { hakkında olumlu şeyler } \\
\text { söylerim. }\end{array}$ & $\%$ & 0,0 & 0,0 & 0,2 & 68,8 & 31,0 & & \\
\hline \multirow{2}{*}{$\begin{array}{l}\text { Anadolu Medeniyetleri Müzesini } \\
\text { arkadaşlarınıza ve yakın çevreme } \\
\text { tavsiye ederim. }\end{array}$} & $\mathrm{f}$ & 0 & 0 & 2 & 270 & 176 & \multirow[b]{2}{*}{4,39} & \multirow[b]{2}{*}{0,49} \\
\hline & $\%$ & 0,0 & 0,0 & 0,4 & 60,3 & 39,3 & & \\
\hline
\end{tabular}

Algılanan hizmet kalitesi, memnuniyet algisı ve tavsiye etme niyeti arasındaki ilişkilere yönelik Spearman korelasyon katsayıları Tablo 4'te sunulmuş olup, değişkenler arasında anlamlı ilişkiler bulunmuştur $(\mathrm{p}<0,01)$.

Korelasyon katsayıları incelendiğinde, algılanan hizmet kalitesi ile memnuniyet algis1 arasinda kuvvetli $(\mathrm{r}=0,650 ; 0,60<\mathrm{r}<0,80)$, algilanan hizmet kalitesi ile tavsiye etme niyeti arasinda orta kuvvette $(\mathrm{r}=0,529 ; 0,40<\mathrm{r}<0,60)$ ve memnuniyet algis1 ile tavsiye etme niyeti arasında ise kuvvetli $(\mathrm{r}=0,714)$ ilişkiler gözlenmiştir.

Tablo 4. Algılanan hizmet kalitesi, memnuniyet algis1 ve tavsiye etme niyeti arasındaki korelasyon katsayıları

\begin{tabular}{lccc}
\hline DEĞişKENLER & Algılanan Hizmet & Memnuniyet & Tavsiye Etme \\
& Kalitesi & Algıs1 & Niyeti \\
\hline Algılanan Hizmet Kalitesi & - & 0,650 & 0,529 \\
Memnuniyet Algis1 & 0,650 & - & 0,714 \\
Tavsiye Etme Niyeti & 0,529 & 0,714 & - \\
\hline
\end{tabular}

Algilanan hizmet kalitesinin memnuniyet algisı (MA) ve tavsiye etme niyeti (TEN) üzerindeki etkisine ilişkin çoklu doğrusal regresyon analizi sonuçları Tablo 5 ve Tablo 6'da sunulmuştur. 
Tablo 5. Algılanan hizmet kalitesinin memnuniyet algısı (MA) üzerindeki etkisine ilişkin çoklu doğrusal regresyon analizi sonuçları

\begin{tabular}{lccccc}
\hline Katsayı & $\boldsymbol{\beta}_{\mathbf{j}}$ & $\mathbf{S H}$ & $\mathbf{t}$ & $\mathbf{p}$ & Anlamlılı \\
\hline Sabit & 1,264 & 0,223 & 5,658 & $0,000^{*}$ & \\
Fiziksel Özellikler & 0,343 & 0,073 & 4,784 & $0,000^{*}$ & \\
(FÖ) & & & & & \\
Heveslilik (H) & 0,185 & 0,051 & 3,632 & $0,000^{*}$ & $\mathrm{~F}=81,944 ;$ \\
İletissim (I) & 0,121 & 0,050 & 2,422 & $0,016^{*}$ & $\mathrm{p}=0,000^{*}$ \\
Tüketilenler (T) & 0,255 & 0,051 & 4,035 & $0,000^{*}$ & \\
Empati (E) & 0,323 & 0,068 & 4,778 & $0,000^{*}$ & \\
\hline
\end{tabular}

${ }^{*} p<0,05 ; R^{2}=0,480$

Her iki tablodaki regresyon modelleri anlamlı bulunmuş $(\mathrm{p}<0,05)$ olup, determinasyon (belirlilik) katsayıları $\mathrm{R}^{2}$ incelendiğinde algılanan hizmet kalitesi faktörleri, memnuniyet algısındaki değişimlerin \%48'ini, tavsiye etme niyetindeki değişimlerin ise $\% 32,3$ 'ünü açıklamaktadır. Tablo 5'e göre memnuniyet algısı üzerinde en etkili hizmet kalitesi faktörleri "fiziksel özellikler", "empati" ve "tüketilenler" olurken, "heveslilik" ve "iletişim" faktörleri diğer faktörlerden daha az etkili bulunmuştur. Bu çerçevede, çoklu doğrusal regresyon modeli;

$$
\mathrm{MA}=1,264+0,343 . \mathrm{S} \ddot{\mathrm{O}}+\mathbf{0 , 1 8 5 .} \mathrm{H}+\mathbf{0 , 1 2 1} . \dot{\mathrm{I}}+\mathbf{0 , 2 5 5 . \mathrm { T }}+\mathbf{0 , 3 2 3 . \mathrm { E }}
$$

şeklinde oluşmuştur. Modele göre, "fiziksel özellikler" boyutundaki 1 birimlik artış memnuniyet algısında 0,343'lük bir artış yaratmaktadır. "Empati” boyutundaki 1 birimlik artış ise memnuniyet algısında 0,323'lük bir artışa neden olacaktır.

Tablo 6'ya göre tavsiye etme niyeti üzerinde en etkili hizmet kalitesi faktörleri "fiziksel özellikler" ve "tüketilenler" olmuştur. Regresyon modeli;

$$
\text { TEN=1,866 + 0,458.SÖ + 0,189.H + 0,138.I }+0,308 . T+0,124 . E
$$

şeklinde kurulmuştur. Bu model, "fiziksel özellikler" boyutundaki 1 birimlik artışın tavsiye etme nedeninde 0,458'lik; "tüketilenler" boyutundaki 1 birimlik artışın ise tavsiye etme niyetinde 0,308 'lik bir artışa neden olacağını ortaya koymaktadır.

Tablo 6. Algılanan hizmet kalitesinin tavsiye etme niyeti üzerindeki etkisine ilişkin çoklu doğrusal regresyon analizi sonuçları

\begin{tabular}{lccccc}
\hline Katsayı & $\boldsymbol{\beta}_{\mathbf{j}}$ & SH & $\mathbf{t}$ & $\mathbf{p}$ & Anlamlılık \\
\hline Sabit & 1,866 & 0,272 & 6,874 & $0,000^{*}$ & \\
Fiziksel Özellikler & 0,458 & 0,088 & 5,181 & $0,000^{*}$ & \\
(FÖ) & & & & & \\
Heveslilik (H) & 0,189 & 0,062 & 3,054 & $0,002^{*}$ & $\mathrm{~F}=42,267 ;$ \\
İletişim (I) & 0,138 & 0,061 & 2,273 & $0,023^{*}$ & $\mathrm{p}=0,000^{*}$ \\
Tüketilenler (T) & 0,308 & 0,062 & 4,996 & $0,000^{*}$ & \\
Empati (E) & 0,124 & 0,082 & 2,222 & $0,033^{*}$ & \\
\hline
\end{tabular}

${ }^{*} p<0,05 ; R^{2}=0,323$

Yukarıdaki bulgular çerçevesinde, araştırmanın; "algılanan hizmet kalitesinin memnuniyet algısı üzerinde anlamlı ve pozitif bir etkisi vardır" ve "algılanan hizmet 
Sert ve Karacaoğlu / Müzelerdeki Hizmet Kalitesinin Memnuniyet Algısı ve Tavsiye Etme Niyeti

Üzerindeki Etkisi: Anadolu Medeniyetleri Müzesi Örneği / The Impact Of Service Quality On Perception of Satisfaction and Intention To Recommend: The Museum of Anatolian Civilizations Case

kalitesinin tavsiye etme niyeti üzerinde anlamlı ve pozitif bir etkisi vardır” şeklindeki temel hipotezlerinin gerçekleştiği sonucuna ulaşılmıştır.

\section{Sonuç ve Tartışma}

Günümüzde işletmeler, hızla değişen bir çevrede faaliyetlerini sürdürmektedir. Dolayısıyla işletmelerin yoğun rekabet ortamında varlığını sürdürebilmesi ve büyümesi büyük ölçüde, hedef pazarın beklediği kalitede ürün ve/veya hizmet sunmasına bağlidır. Müzeler de ticari işletmeler gibi ziyaretçi çekmek için birbiriyle yarışan kurumlardır. $\mathrm{Bu}$ nedenle, müzelerin ziyaretçilerine sunduğu hizmet kalitesinin önemli bir pazarlama ve rekabet aracı haline geldiği söylenebilir. Müzelerde hizmet kalitesinin ölçülmesi bir hizmet boyutunun hangi yönlerinin sorun oluşturabileceğini ortaya koymakta ve böylece problemin giderilmesi için öneriler geliştirilmesine imkan tanımaktadır. Ayrıca hizmeti iyileştirmek amacıyla uygulanan bu önerilerin başarılı olma durumları da uygulamanın öncesinin ve sonrasının ölçülüp karşılaş̧ırılmasıyla izlenebilmektedir (Frochot, 2001; Frochot ve Hughes, 2000). Anadolu Medeniyetleri Müzesi, 1997 y1lında İsviçre'nin Lozan kentinde 68 Müze arasında birinci seçilerek "Avrupa'da Yııın Müzesi” unvanını kazanmıştır (Anadolu Medeniyetleri Müzesi, 2018). Buradan yola çıkarak araştırmada, Anadolu Medeniyetleri Müzesi'ni ziyaret eden kişilerin algıladığı hizmet kalitesi ve hizmet kalitesi algısının memnuniyet algısı ile tavsiye etme niyeti üzerindeki etkisi incelenmiştir.

Araştırmanın bulgularına göre, "fiziksel özellikler", "heveslilik", “iletişim", "tüketilenler" ve "empati" olmak üzere 5 boyutta incelenen algılanan hizmet kalitesi ölçeği, daha önce Allen, (2001), Frochot, (2001), Hsieh (2010), Cheng ve Wan (2012) ve Hsieh vd., (2015) tarafından yapılan çalışmalarda müzelerdeki hizmet kalitesini ölçmek amacıyla kullanılan ölçeklere boyutlar bakımından benzerlik göstermektedir. Bu doğrultuda, ilgili kurumlar, kuruluşlar ve özellikle müze yöneticileri, beş boyuttan oluşan bu ölçeği kullanarak müzelerde iyileştirilmesi gereken hizmet kalitesi alanlarını belirleyebilir ve gerekli önemleri alabilirler. Ayrıca, daha sonra bu hizmet alanlarında herhangi bir gelişme olup olmadığını, aldıkları önlemlerin yeterliliğini yine bu ölçeği kullanarak izleyebilirler.

Araştırmayla elde edilen bulgular, ziyaretçilerin Anadolu Medeniyetleri Müzesi'nin hizmet kalitesine ilişkin genel olarak olumlu bir tutum sergilediklerini göstermektedir. Hizmet kalitesi açısından ziyaretçiler tarafindan en olumlu bulunan boyutun müze personelinin tutumuyla ve hizmet sunuş şekliyle ilgili olan "heveslilik" boyutu olduğu saptanmıştır. Ziyaretçilerin olumlu olarak algıladığı diğer boyutlar sırasıyla "fiziksel özellikler", "iletişim", "empati" ve son olarak "tüketilenler" olarak tespit edilmiştir. Alan yazın incelendiğinde araştırma sonucunun, ziyaretçiler tarafından algılanan en olumlu boyut bağlamında diğer çalışmalarla farklılıklar içerdiği görülmektedir. Cheng ve Wan (2012) ve Hsieh vd.'nin (2015) çalışmalarında “fiziksel özellikler”in ziyaretçiler tarafından algılanan en olumlu boyut olduğu bildirilmiştir. Bu araştırmada ise fiziksel özellikler boyutu en olumlu ikinci boyut olarak tespit edilmiştir. Bunun nedeni bu boyut altında yer alan "yeterli park yeri vardır" ifadesine verilen olumsuz cevaplar olduğu düşünülmektedir. Ziyaretçilerin büyük bir kısmı Anadolu Medeniyetleri Müzesi'nde yeterli park yerinin olmadığını düşünmekte olup en olumsuz yaklaşım bu ifadeyle ilgilidir. Toplu taşıma araçlarıyla müzeye direkt ulaşımın olmaması ve müze etrafinda park yerinin yetersiz olmasından dolayı özel araçlarıyla gelen ziyaretçilerin park yeri sıkıntısı yaşamasının hizmet kalitesi açısından fiziksel özellikler boyutuna olan olumlu algıyı ikinci plana düşürdüğü söylenebilir. $\mathrm{Bu}$ 
noktada, müze yönetiminin hizmet kalitesini arttırmak için ziyaretçilerin araçlarını rahatlıkla park edebilecekleri bir park yeri yapmaları önerilebilir.

Öte yandan, çalışmanın diğer bir sonucuna göre algılanan hizmet kalitesini en çok etkileyen boyut ise "fiziksel özellikler" boyutu olarak bulgulanmıştır. Bunu sırasıyla; "tüketilenler", "empati", "iletişim" ve son olarak "heveslilik" boyutu izlemektedir. Söz konusu bulgu Frochot'un (2001), çalışmasıyla örtüşmekte olup HISTOQUAL ölçeğinde de "fiziksel özellikler" in hizmet kalitesini en çok etkileyen boyut olduğu belirlenmiştir. Ancak farklı olarak Frochot'un (2001) çalışmasında hizmet kalitesini en az etkileyen boyut "empati" olarak saptanmıştır. Araştırma sonuçları, "fiziksel özellikler" boyutunda Anadolu Medeniyetleri Müzesi'nde sergilenen eserlerin çok çeşitli olmasının ve müzenin temiz olmasının hizmet kalitesinin olumlu algılanmasında önemli unsurlar olduğunu göstermektedir. Söz konusu bulgular, Nowacki'nin (2005), Yücelt'in (2000), Frochot'un (2001) ve Maher ve Clark'nn (2005), Hui-Ying ve Chao-Chien'in (2008), Lin'in (2009), Wu ve Li'nin (2015), Hsieh ve arkadaşlarının (2015) çalışmasıyla örtüşmektedir.

Araştırma sonuçları, müze ziyaretçilerinin "tüketilenler" boyutunda hediyelik eşya satış yeri ve kafeteryada satılan yiyecek içecek çeşidinin çok olduğuna ilişkin ifadelere diğer ifadelere göre daha olumsuz yaklaşım gösterdiklerini işaret etmektedir. Öte yandan, kafeterya çalışanlarının iyi hizmet verdiği ve hediyelik eşyaların kaliteli olduğuna ilişkin ifadelere ise daha olumlu yaklaşım gösterildiği saptanmıştır. Söz konusu bulgular ışığında, hediyelik eşya satış yeri ile kafeteryanın büyütülmesinin ve özellikle de burada sunulan ürün çeşidinin arttırılmasının müzeyle ilgili hizmet kalitesi algısını olumlu yönde etkileyeceği düşünülmektedir. Araştırmaya katılan ziyaretçilerin "empati" boyutunda yer alan müze atmosferinin sergilenen eserlere uyduğuna ilişkin ifadeye olumlu görüş bildirdiği görülmektedir. Öte yandan, engelli ziyaretçilerin müzeyi rahatlıkla gezebilmeleri için gerekli düzenlemelerin yapıldığı ifadesine ve çocuklar için imkânlar yeterlidir ifadesine olumsuz yaklaşıldığı tespit edilmiştir. Bu sonuç, araştırmaya katılanların müzede engelli ziyaretçilerin rahatça gezmelerini sağlayacak düzenlemelerin yeterince yapılmadığını, çocukların ilgisinin yeterince çekilmediğini düşündüğünü, göstermektedir. Müzelerle ilgili diğer çalışmalarda da (Frochot ve Hughes, 2000; Frocht, 2001; Mylonakis ve Kendristakis, 2006) belirtildiği üzere engelli ziyaretçilerin müzede rahatça dolaşabilmelerini sağlayacak düzenlemelerin yapılması oldukça önemlidir. $\mathrm{Bu}$ bağlamda müze yönetiminin engelli ziyaretçilerin ihtiyaç ve beklentilerine uygun düzenlemeler ile iyileştirmeler yapmasının, ve çocukların daha çok ilgisini çekebilmek için simülasyon görüntülerinin arttırılmasının Anadolu Medeniyetleri Müzesi'nin hizmet kalitesini arttıracağı öngörülmektedir. Farklı yaş gruplarından öğrenciler için ücretli ve/veya ücretsiz eğitim programlarıyla kültür-sanat etkinlikleri düzenlenebilir. Çocukların ve gençlerin tarih ve arkeolojiye olan ilgi ve bilgilerini artırmaya yönelik uygulamalı eğitimler ile eğlenceli etkinlikler yapılabilir. Müze atmosferini daha çekici kılmak amacıyla müze ortamına uygun hafif bir müziğin çalınması sağlanabilir.

Bir diğer boyut olan "iletişim" boyutunda tasarım, sergileme ve işaretlerin boyutu, 1şığın parlaklığg gibi ifadelere ilişkin olumlu yaklaşımın yüksek olduğu görülmektedir. Öte yandan broşürler ve web sitesinin yeterli bilgi sunduğuna ilişkin ifadeye olan katılım ise en az olmuştur. Söz konusu bulgudan hareketle Anadolu Medeniyetleri Müzesi yönetiminin sergilenen eserlerle ilgili broşür ve kitapçıklar hazırlamaları ve bunları müze girişinde ziyaretçilere sunmalarının ve rehberli turların düzenlenmesinin algılanan hizmet kalitesine olumlu katkı sağlayacağı söylenebilir. Bu bağlamda haftanın belirli günleri (özellikle 
ziyaretçilerin yoğun olduğu hafta sonları) sözkonusu turlar müzede görevli rehberlerle yapılabileceği gibi müze yönetiminin üniversitelerle yapacağ 1 işbirliği doğrultusunda turist rehberliği, arkeoloji, sanat tarihi, tarih vb. bölümlerde eğitim almış öğrencilerin eşliğinde gerçekleştirilebilir. Son olarak, "heveslilik" boyutunda müze personelinin anında ve iyi hizmet verdiği ayrıca cana yakın olduğuna ilişkin ifadelere katılımın birbirine yakın olduğu görülmektedir.

Çalışmada, mevcut alan yazından hareketle, iki adet hipotez geliştirilmiş ve test edilmiştir. İlk hipotez testi sonucunda, ziyaretçilerin algıladığ memnuniyet algısını anlamlı ve pozitif etkilediği tespit edilmiştir. Bu durum, mevcut alan yazından Hui-Ying ve Chao-Chien (2008), Lin (2009), Mey ve Mohamed (2010), Wu ve Li'nin (2015) çalışmaları ile benzerlik göstermektedir. Memnuniyet algısını en çok etkileyen hizmet kalitesi boyutunun yeterli park yerinin olmas1, tuvaletlerin durumu, müze görevlilerinin giyimi, sergilerin korunması, müzenin temiz olmas1, müzede oturma yerlerinin yeterli olması ve müzede sergilenen eserlerin çeşitliliği gibi ifadeleri içeren "fiziksel özellikler" olduğu ve bunu takiben "heveslilik", "iletişim", "tüketilenler" ve son olarak da "empati” boyutunun geldiği görülmüştür. Söz konusu bulgunun, bir müzenin fiziksel özelliklerinin ziyaretçilerin memnuniyetini etkilediğine ilişkin atıfta bulunan çalışmaların sonuçlarıyla örtüştügü görülmektedir (Goulding, 2000; Lehn, 2005; Nowacki, 2005; Chen ve Wan, 2012).

Araştırmada test edilen ikinci hipotezin sonucu, algılanan hizmet kalitesinin tavsiye etme niyetini etkilediğini, tavsiye etme niyeti üzerinde anlamlı ve pozitif bir etkisi olduğunu göstermektedir. Bu sonuç, ilgili alan yazındaki çalışmalarla benzerlik göstermektedir (HuiYing ve Chao-Chien, 2008; Mey ve Mohamed, 2010; Wu ve Li, 2015). "Fiziksel özellikler"in tavsiye etme niyetini en çok etkileyen faktör olduğu bulgulanmıştır. Tavsiye etme niyetini etkileyen diğer boyutlar sırasıyla "heveslilik", "iletişim", "tüketilenler" ve son olarak da "empati" olarak tespit edilmiştir. Özet olarak algılanan hizmet kalitesinin ölçülmesi, müze yöneticilerinin dikkat etmesi gereken hizmet alanlarını belirleyip bu alanlara öncelik vermelerine böylece hizmet kalitesinde ve ziyaretçi memnuniyetinde iyileştirmeler sağlamasına dolayısıyla tavsiye etme niyetini olumlu etkilemelerine olanak tanıyabilir.

Yapılan alan araştırmasının bir dizi kısıtı bulunmaktadır. Kısıtlardan ilki yerli ziyaretçilerle ve kolayda örnekleme yöntemi ile sınırlı olmasıdır. Bunun temel nedeni verilerin sınırlı sürede toplanmış olmasıdır. Dolayısıyla, ileriki yıllarda yapılacak araştırmalarda verilerin daha geniş zaman aralığında toplanması, örneklem büyüklüğünün arttırılması ve farklı örnekleme yöntemlerinin kullanılması yararlı olacaktır. Bu çalışmanın müze yönetimi ve pazarlaması alanlarına katkıda bulunacağı ve yol gösterici bir nitelik taşıyacağı düşünülmektedir. Ancak gerek müzelerin çeşitliliği ve bu çalışmada veri toplanılan örneklemin büyüklüğü göz önünde bulundurulduğunda çalışmanın sonuçlarının tüm müzeler için genellenebilir olduğunu söylemek yanıltıcı olacaktır. Öte yandan, hizmet kalitesi, ziyaretçi memnuniyeti ve tavsiye etme niyeti arasındaki ilişkilerin ülkemizdeki farklı müze ortamlarında da araştırılmasının ve karşılaştırılmasının ilgili alan yazının gelişmesine katkı sağlayacağı düşünülmektedir.

\section{Kaynakça}


Allen, E. (2001). Can the neglect of defining and evaluating service quality in museums be effectively addressed by SERVQUAL? (Unpublished MA Thesis). The Nottingham Trent University.

Andreasen A. R. ve Kotler, P. (2002). Strategic Marketing for Non Profit Organizations (5th ed.). Upper Saddle River, NJ: Prentice Hall.

Anadolu Medeniyetleri Müzesi (2018). Anadolu Medeniyetleri Müzesi. http://www.anadolumedeniyetlerimuzesi.gov.tr/ (Erişim Tarihi 10.02.2018).

Baker D. A. ve Crompton J.L. (2000). Quality, Satisfaction and Behavioral Intentions. Annals of Tourism Research, 27(3), 785-804.

Black, G. (2005). The engaging museum, developing museums for visitor involvement: Londo-Rutledge.

Burton C. ve Scott C. (2003). Challenges for the 21st Century. International Journal of Arts Management, 5(2), 56-68.

Caldwell, N. (2002). (Rethinking) the measurement of service quality in museums and galleries. International Journal of Nonprofit and Voluntary Sector Marketing, 7(2), 161171.

Caro, L.M. ve. Garcia, J.A.M. (2008). Developing a multidimensional and hierarchical service quality model for the travel agency industry. Tourism Management, 29(1), 706720.

Cheng IM. ve Wan, YKP. (2012). Service Quality of Macao Museums. Journal of Quality Assurance in Hospitality ve Tourism, 13(1), 37-60.

Dabholkar, P.A. (1996). Consumer evaluations of new technology-based self-service operations: an investigation of alternative models. International Journal of Research in Marketing, 13(1), 29-51.

Dabholkar, P.A., Shepherd, C.D. ve Thorpe, D.I. (2000). A comprehensive framework for service quality: an investigation of critical conceptual and measurement issues through a longitudinal study, Journal of Retailing, 76(2), 131-9.

Dotchin, J.A. ve Oakland, J.S (1994). Total Quality Management in Services. International Journal of Quality ve Reliability Management, 11(3), 9-26.

Duman, T. (2003), Richard L. Oliver'in Tüketici Memnuniyeti ve Tüketici Değer Algis1 Kavramları Hakkındaki Görüşleri: Teorik Bir Karşılaştırma. Dokuz Eylül Üniversitesi Sosyal Bilimler Enstitüsü Dergisi, 5(2), 45-56.

Efil, İ. (1999). Toplam kalite yönetimi ve ISO 9000 Kalite Güvence Sistemi (4. bask1.). İstanbul: Alfa.

Eskiler, E. ve Altunışık, R. (2015). Algılanan Değer ve Müşteri Memnuniyetinin Satın Alma Eğilimleri Üzerine Etkisi. III. Rekreasyon Araştırmaları Kongresi, 5-7 Kasım, Eskişehir, ss. 483-493.

Falk, J.H. (2009). Identity and The Museum Visitor Experience. Newyork: Routlegde.

Feigenbaum, A. V. (1991). Total Quality Control, (3. ed.). New York: McGraw-Hill.

Frost, F. A. ve Kumar, M. (2000). INTSERVQUAL-an internal adaptation of the GAPmodel in a large service organisation. Journal of Services Marketing, 14 (5), 358-377.

Frochot, I. (2001). Measurement of Service Qualit, in : Quality Issues in Heritage Visitor Attractions (Eds: S. Drummond., ve I. Yeoman.), Oxford, UK: Butterworth-Heinemann.

Frochot, I. ve Hughes, H. (2000). HISTOQUAL: The development of a historic houses assessment scale. Tourism Management, 21(2), 157-167.

Gilmore, A. ve Rentschler, R. (2002). Changes in museum management A custodial or marketing emphasis?, Journal of Management Development, 21(10), 745-760. 
Sert ve Karacaoğlu / Müzelerdeki Hizmet Kalitesinin Memnuniyet Algısı ve Tavsiye Etme Niyeti Satisfaction and Intention To Recommend: The Museum of Anatolian Civilizations Case

Grönroos, C. (1984). A Service Quality Model and Its Marketing Implications. European Journal of Marketing, 18(4), 36-44.

Goulding, C. (2000). The museum environment and the visitor experience. European Journal of Marketing, 34(3/4), 261-278.

Harrison P. ve Shaw R. (2004). Consumer Satisfaction and Post-purchase Intentions: An Exploratory Study of Museum Visitors. International Journal of Arts Management, 6(2), 23-32.

Hui-Ying, S. ve Chao-Chien, C. (2008). A Study of Service Quality and Satisfaction for Museums - Taking the National Museum of Prehistory as an Example. The Journal of Human Resource and Adult Learning, 14(1), 159-170.

Hsieh, C. M. (2010). Roles of motivations, past experience, perceptions of service quality, value and satisfaction in museum visitors' loyalty. Dissertation, Michigan State University.

Hsieh, C.M, Park, S. H. ve Hitchcock, M. J. (2015). Examining the relationships among motivation, service quality and loyalty: The case of the National Museum of Natural Science (NMNS). Asia Pacific Journal of Tourism Research, 20 (1), 1505-1526.

Hosany, S., Prayag, G., Deesilatham, S., Cauševic, S. ve Odeh, K. (2015). Measuring tourists' emotional experiences: Further validation of the destination emotion scale. Journal of Travel Research, 54(4), 482-495.

Huang, P.L., Lee, B.C.Y. ve Chen C.C. (2017). The Influence of Service Quality on Customer Satisfaction and Loyalty in B2B Technology Service Industry. Total Quality Management ve Business Excellence, 14(1), 1-17.

Huo Y., ve Miller D. (2007). Satisfaction Measurement of Small Tourism Sector (Museum): Samoa. Asia Pacific Journal of Tourism Research, 12(2), 103-117.

Juran, J. M. (1988). Juran's Quality Control Handbook, 4th Edition, Ed. By Juran and Frank M. Gryna, Mc Graw Hill. Co., New York.

ICOM (2007). Museum Definition. http://icom.museum/the-vision/museum-definition/ adresinden 10.02.2018 tarihinde erișilmiștir.

ISO 9000. (2000). International Standard Organisation. Quality management systems Fundamentals and vocabulary. https://www.iso.org/standard/29280.html (Erişim 30.11.2017).

Kawashima, N. (1998). Knowing the Public: A Review of Museum Marketing Literature and Research. Museum Management and Curatorship, 19(1), 21-39.

Kültür ve Turizm Bakanlığ1, (2018). Anadolu Medeniyetleri Müzesi. https://www.muze.gov.tr/tr/muzeler/anadolu-medeniyetleri-muzesi (Erişim Tarihi 10.02.2018)

Lin, Y.N. (2009). Importanceperformance analysis of the Taipei Fine Arts Museum's services. Museum Management and Curatorship, 24(2), 105-121.

Maher, J.K.ve Clark, J. (2005). Servqual Dimensions: A Comparison Between Retail Banking and a Museum. Proceedings of the Annual Meeting of the Association of Collegiate Marketing Educators, 161-162.

Maher, J. K., Clark, J. C. ve Motley, D. G. (2011). Measuring museum service quality in relationship to visitors membership: The case of a children's museum. International Journal of Arts Management, 13(2), 29-42.

Markovic, S., Raspor, S., ve Komsic, J. (2013). Museum Service Quality Measurement Using The Histoqual Model. Tourism in Southern and Eastern Europe, 201-216. 
Mey, L.P. ve Mohamed, B. (2010). Service Quality, Visitor Satisfaction and Behavioural Intentions: Pilot Study at a Museum In Malaysia. Journal Of Global Business and Economics, 1(1), 226-240.

McLean, F. (1994). Services Marketing: The Case of Museums. Services Industries Journal, 14 (2), 190-203.

Mylonakis, J. ve Kendristakis, E. (2006). Evaluation of museums service quality: A research study of museums and galleries visitors' satisfaction. Tourism and Hospitality Management, 72(2), 37-54.

Nowacki, M.M. (2005). Evaluating a museum as a tourist product using the SERVQAUL method. Museum Management and Curatorship, 20(3), 235-250.

Oliver, R. L. (1980). A Cognitive Model of the Antecedents and Consequences of Satisfaction Decisions. Journal of Marketing Research, 17(4), 460-469.

Oliver, R. L. (1981). Measurement and Evaluation of Satisfaction Processes in Retail Settings. Journal of Retailing, 57(3), 25-48.

Parasuraman, A., Zeithaml, V.A. ve Berry, L.L. (1985). A Conceptual Model of Service Quality and Its Implications for Future Research. Journal of Marketing, 49(4), 41-50.

Parasuraman, A., Zeithaml, V.A. ve Berry, L.L. (1988). SERVQUAL: A Multiple- Item Scale for Measuring Consumer Perception of Service Quality. Journal of Retailing, 64(1), 12-40.

Parasuraman, A., Zeithaml, V.A. ve Berry, L.L. (1994). Reassesment of Expectations as a Comparison Standard in Measuring Service Quality: Implications for Further Research. Journal of Marketing, 58(1), 111-124.

Reid, L.J. ve Reid, S.D.(1993). Communicating Tourism Suppliers: Services Building Repeat Visitor Relationships. Journal of Travel and Tourism Marketing, 2(2/3), 3-20.

Philip, G. ve Hazlett, S. A. (1997). The measurement of service quality: a new P-C-P attributes model. International Journal of Quality ve Reliability Management, 14(3), 260-286.

Rowley, J. (1999). Measuring Total Customer Experience in Museums". International Journal of Contemporary Hospitality Management, 11(6), 303-308.

Rust R. ve Oliver, R.L. (2000). Should We Delight the Customer? Journal of the Academy of Marketing Science, 28(1), 86-94.

Saltuk, S. (1993). Arkeoloji Sözlü̈̆̈̈, İstanbul: İnkılap Yayınevi (2. Bask1).

Santos, J. (2003). E-service Quality: A model of virtual service quality dimensions. Managing Service Quality, 13(13), 233-46.

Seth, N., Deshmukh, S.G. ve Vrat, P. (2005). Service Quality Models: a Review. International Journal of Quality ve Reliability Management, 22(9),913-949.

Spreng, R. ve A. Mackoy, R.D.(1996). An Empirical Examination of a Model of Perceived Service Quality and Satisfaction. Journal of Retailing, 72(2), 201-214.

Swarbrooke, J.(2002). The Development and Management of Visitor Attractions, 2nd ed. London: Butterworth-Heinemann.

Taylor, S. A. ve Cronin, J.J. (1994). Modeling Patient Satisfaction and Service Quality. Journal of Health Care Marketing,14(1), 34-44.

Williams, C. (1998). Is the SERVQUAL model an appropriate management tool for measuring service delivery quality in the UK leisure industrystry?, Managing Leisure, 3(2), 98-110.

Wu, H.C. ve Li, T. (2015). An Empirical Study of the Effects of Service Quality, Visitor Satisfaction, and Emotions on Behavioral Intentions of Visitors to the Museums of Macau. Journal of Quality Assurance in Hospitality ve Tourism, 16(1), 80-102. 
Yarımoğlu Kursunluoglu, M. (2014). Review on Dimensions of Service Quality Models. Journal of Marketing Management, 2(2), 79-93.

Yücelt, U. (2000), Marketing Museums: An Empirical Investigation Among Museum Visitors. Journal of Nonprofit ve Public Sector Marketing, 8(3), 3-13.

Zeithaml V. A. Berry L.L., ve A. Parasuraman A. (1996). The Behavioral Consequences of Service Quality. Journal of Marketing, 60(2), 31-46.

Zeithaml, V. ve Bitner, M. (2000). Services Marketing: Integrating Customer Focus Across the Firm, 2d ed. Boston: Irwin/McGraw-Hill. 